\title{
Investigating Leachate Transport at Landfill Site Using HYDRUS-1D
}

\author{
A. H. M. Faisal Anwar and Larissa Chan Thien
}

\begin{abstract}
Landfill leachate is a very common environmental problem that might contaminate underlying soil and groundwater. This paper investigates the potential leachate of heavy metals from the landfill site of Rottnest Island in Western Australia. The heavy metals selected for this study was Copper and Zinc as high concentration of these metals was found in Rottnest groundwater. The migration of heavy metal leachate through the soil profile was modelled using HYDRUS-1D. The model was developed for site specific conditions of Rottnest Island landfill site for the period 1996-2010 for different soil-water-chemical interaction parameters. The results show that the adsorption coefficient $k_{d}\left(\mathrm{~cm}^{3} / \mathrm{g}\right)$ is the most significant parameter that dominates the heavy metal migration in soil. The initial concentration also shows significant effect on leachate contamination. The longitudinal dispersion was found with moderate significance in solute transport but diffusion coefficient has no effect on contaminant migration in soil. However, initial soil moisture and saturated hydraulic conductivity showed minimum effect on leachate transport in this landfill site.
\end{abstract}

Index Terms-Landfill site, heavy metals, leachate, contamination, soil.

\section{INTRODUCTION}

Environmental protection for leachate control has become an increasingly important towards sustainable management of solid waste. Due to the increased population globally, the generation of solid waste has also increased significantly. Every day, a large amount of solid wastes are generated due to human activities which are either typically landfilled or incinerated. The later includes burning of solid waste. Releases of heavy metals to the environment may occur by volatilization in incineration, or in the event of fires at landfills, transfer station and recycled centers or via landfill leachate [1]. Although land filling is one of the most common method of solid waste disposal in many countries, but it has high risk in polluting the underlying soil and groundwater if the landfill site is not controlled and designed properly. That is why, it is important to monitor the leachate transport underneath the landfill on timely manner. The rate of contaminant migration depends on the physical, chemical and biological processes in the soil profile and the nature of the contaminant disposed at the landfill [2]-[5]. The contaminants (e.g. heavy metals) releasing on ground surface flow down through the unsaturated zone and penetrate into the groundwater. This has led to rapid development of analytical and technological tools to understand the transportation of landfill leachate in soil for the prediction of

Manuscript received November 12, 2014; revised January 5, 2015.

The authors are with the Department of Civil Engineering at Curtin University, Perth Western Australia (e-mail: f.anwar@curtin.edu.au) potential contaminant concentration in groundwater. There are various mathematical models used for this purpose such as, analytical or numerical techniques [6], [7]. Numerical models provide adaptability and capability for complicated field conditions. Simulating contaminant transport in soil by the use of mathematical model shows a better way of solving environmental issues because it provides realistic measures [8], [9]. The primary objective of this paper is to investigate the migration of landfill leachate and the concentration of leachate constituent through a soil profile of Rottnest Island using a mathematical model HYDRUS-1D.

\section{SITE CHARACTERISTICS}

\section{A. Rottnest Island}

The landfill site at Rottnest Island in Western Australia was selected as the study area for this research. Rottnest Island is a popular recreation island, located at latitude $32.002^{\circ} \mathrm{S}$ and longitude $115.517^{\circ} \mathrm{E}$ on the southwest coast of Western Australia, $18 \mathrm{~km}$ west of Fremantle. It is an A-class reserve of 2000 hectares of which $10 \%$ is made up of salt lakes [10]. The island is mainly built out of thick layers of Tamala limestone, a medium to coarse - medium-grained calcarenite, overlain by thin layer of the Herschell limestone and safety bay sands. The average annual rainfall on the island is $704 \mathrm{~mm}$.

\section{B. Landfill Site}

The biggest constraint to the waste management at Rottnest Island is its remote geographical location, $18 \mathrm{~km}$ away from the mainland in the Indian Ocean. The island established a landfill site of 2 hectares located approximately $1.2 \mathrm{~km}$ west of the main settlement area in 1992 to dispose a series of waste including mixed municipal waste, food waste, bio-solids, cardboard, paper and construction waste. It was an unlined landfill and its first cell was capped in 1996 and the second cell was capped in 2002. Unlined landfill site can easily cause leachate migration from the landfill during rain events and can contaminate underlying groundwater. Department of Environmental Protection hence decided to stop the option of cutting the fourth cell and closed the site for further disposal in 2005 .

\section{Groundwater Quality}

The main freshwater resources at Rottnest Island are the two shallow unconfined aquifers known as Oliver Hill and Wadjemup mounds. These aquifers are linked with nearby salt lakes and that is why the groundwater near lakes found with high salinity known as brackish water. Boreholes with depth of average $14 \mathrm{~m}$ are set up around the landfill site for groundwater monitoring. The groundwater sampling from 
the boreholes showed that there are heavy metals concentrations exceeding the guidelines given by ANZECC for fresh and marine water quality [11]. For example, maximum copper and zinc concentration in landfill groundwater was found $0.015 \mathrm{mg} / \mathrm{L}$ and $0.062 \mathrm{mg} / \mathrm{L}$ [12]. But the maximum permissible limit for Copper and Zinc concentration are $0.0014 \mathrm{mg} / \mathrm{L}$ and $0.008 \mathrm{mg} / \mathrm{L}$ respectively in ANZECC guidelines [11]. For this reason, the transport of Copper and Zinc was considered in this study.

\section{HYDRUS 1D MODEL}

The HYDRUS 1D is a one dimensional finite-element model that simulates the movement of water, heat and multiple solutes in variably saturated conditions [13]. The water movement in soil is modelled by Richard's equation:

$$
\frac{\delta \theta}{\delta t}=\frac{\delta}{\delta x}\left[K\left(\frac{\delta h}{\delta x}-\cos \alpha\right)\right]
$$

where, $h$ is the hydraulic potential of water or water pressure head (L) which is the summation of suction head and gravity head, the $\theta$ represents the volumetric water content, $t$ is the time, $x$ is the spatial coordinate (L) with upwards as positive, $\alpha$ is the angle between the flow direction and the vertical axis (for example, $\alpha=0^{\circ}$ for vertical flow, $90^{\circ}$ for horizontal flow, and $0^{\circ}<\alpha<90^{\circ}$ for inclined flow) and $\mathrm{K}$ is the unsaturated hydraulic conductivity (m/day).

The Fickian's Advection-Dispersion equation used for the solute transport in the model is:

$$
\frac{\delta c}{\delta t}=D \frac{\delta^{2} c}{\delta x^{2}}-v \frac{\delta c}{\delta x}
$$

where $c$ is the concentration of the solute $\left(\mathrm{ML}^{-3}\right), x$ is the depth of the soil (L), $t$ is the time taken for the transportation between the soil surface and the depth (T), D represents the hydrodynamic dispersion coefficient of the solute $\left(\mathrm{L}^{2} \mathrm{~T}^{-1}\right)$ and $v$ is the velocity of the travelling solute $\left(\mathrm{MT}^{-1}\right)$.

The two governing equations are solved using the Crank-Nicholson implicit scheme for time weighting scheme and Galerkin finite elements for the space weighting scheme.

\section{MODEL PARAMETERS}

The initial water content, $\theta$ of the soil profile is set at 0.1 (default setting) for $14 \mathrm{~m}$ depth of soil profile. The initial concentrations of both heavy metals are set at $100 \mathrm{mg} / \mathrm{L}$ and $10 \mathrm{~g} / \mathrm{L}$ respectively for two types of simulations. The upper boundary condition is set as an 'Atmospheric boundary' with surface runoff. The lower boundary condition is considered to be a free drainage for a landfill site. However, the model was run for 15 years (1996-2010) with Rottnest Island mean monthly precipitation records $(n=179)$. For limestone, the bulk density values ranges from $1.3-2.6 \mathrm{~g} / \mathrm{cm}^{3}$ depending on the form of the limestone. The average bulk density for most limestone is taken as $1.5 \mathrm{~g} / \mathrm{cm}^{3}$ and therefore, it is left at the default setting of $1.5 \mathrm{~g} / \mathrm{cm}^{3}$. The leaching potential was evaluated under the soil type of limestone and the Van Genuchtan soil hydraulic properties are shown in Table I. The soil distribution coefficient or adsorption coefficient $k_{d}$, is a measure of the chemicals ability to leach and the final concentration of the leachate through the groundwater. For this reason, it is very important to investigate the effects of interaction between soil and the heavy metals by varying $k_{d}$ values. The value of $k_{d}$ was set for Copper and Zinc at $4.0 \times 10^{-5} \mathrm{~m}^{3} / \mathrm{g}$ and $1.6 \times 10^{-5} \mathrm{~m}^{3} / \mathrm{g}$ respectively. The diffusion coefficients, $\mathrm{D}_{W}$ of Copper and Zinc in free water were considered zero.

TABLE I: THE VAN GeNUCHTEN HydRAULIC PARAMETERS FOR SOIL

\begin{tabular}{c|c|c|c|c|c|c}
\hline \hline Material Type & $\begin{array}{c}\Theta_{r} \\
(\%)\end{array}$ & $\begin{array}{c}\Theta_{s} \\
(\%)\end{array}$ & $\alpha\left(\mathrm{m}^{-1}\right)$ & $\mathrm{N}$ & $\begin{array}{c}\mathrm{K}_{s} \\
(\mathrm{~m} / \text { day })\end{array}$ & Reference \\
\hline $\begin{array}{c}\text { Tamala } \\
\text { Limestone }\end{array}$ & 0 & 11 & 0.0365 & 1.83 & 86.4 & $\begin{array}{c}\text { Roulier, } \text { et al. } \\
{[14]}\end{array}$ \\
\hline \hline
\end{tabular}

\section{RESUlTS AND DISCUSSION}

\section{A. Effect of Initial Concentration}

In order to check the effect of initial concentration on leachate migration, modelling was performed for two initial concentrations (e.g. $10 \mathrm{~g} / \mathrm{L}$ and $100 \mathrm{mg} / \mathrm{L}$ ) for selected heavy metals (Copper and Zinc). The observation nodes (N1-N8) were considered at $1 \mathrm{~m}, 2 \mathrm{~m}, 4 \mathrm{~m}, 6 \mathrm{~m}, 8 \mathrm{~m}, 10 \mathrm{~m}, 12 \mathrm{~m}$, and $14 \mathrm{~m}$ depth along the soil profile. The simulation results are shown in Fig. 1 ( $a$ and $b$ ) and Fig. 2 ( $a$ and $b$ ) respectively for two initial concentrations.

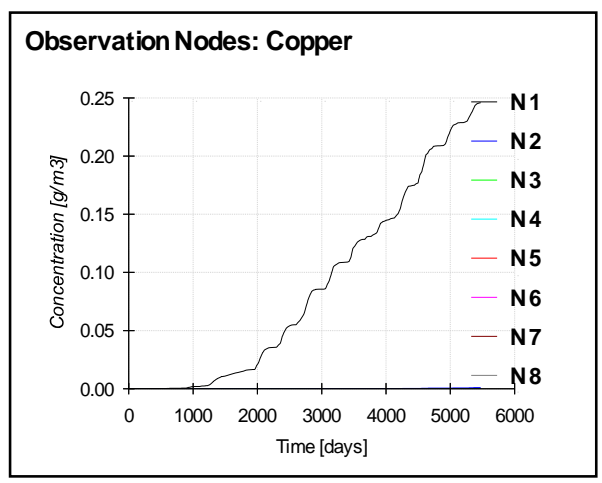

Fig. 1a. Copper concentrations through soil profile with initial concentration of $10 \mathrm{~g} / \mathrm{L}$.

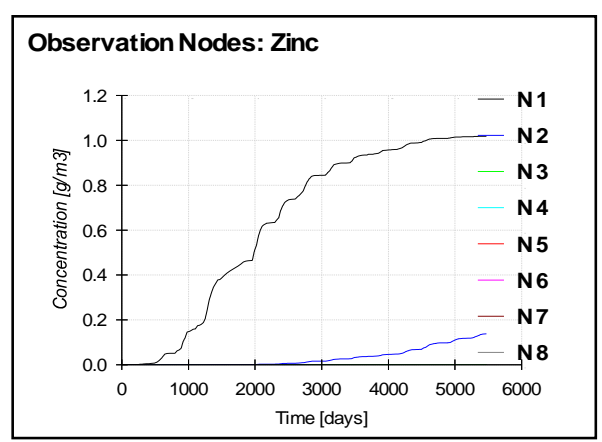

Fig. 1b. Zinc concentrations through soil profile with initial concentration of $10 \mathrm{~g} / \mathrm{L}$

The results revealed that the Zinc concentration was found much higher than the Copper concentration in soil. The copper leachate reached $1 \mathrm{~m}$ depth after the end of third year and it has a concentration of $0.00245 \mathrm{mg} / \mathrm{L}$ after 15 years (end of modelling period) when initial concentration was considered $10 \mathrm{~g} / \mathrm{L}$. For the same initial concentration of $10 \mathrm{~g} / \mathrm{L}$, the Zinc leachate reached at $1 \mathrm{~m}$ depth after 15 years with a concentration of $0.0102 \mathrm{mg} / \mathrm{L}$ and entered at $2 \mathrm{~m}$ depth after 7 years. The accumulated Zinc concentration was found 
to be $0.0016 \mathrm{mg} / \mathrm{L}$ after the end of 15 years. The similar nature of heavy metal migration was obtained with the initial concentration of $100 \mathrm{mg} / \mathrm{L}$ for both heavy metals but concentration in soil was found 100 times less with a 10 times less initial concentration. This indicates lower concentration of heavy metal leachate from landfill site will have significantly lower possibility of leaching through the soil. However, these values were found less than the maximum permissible value of these metals given in ANZECC guidelines [11].

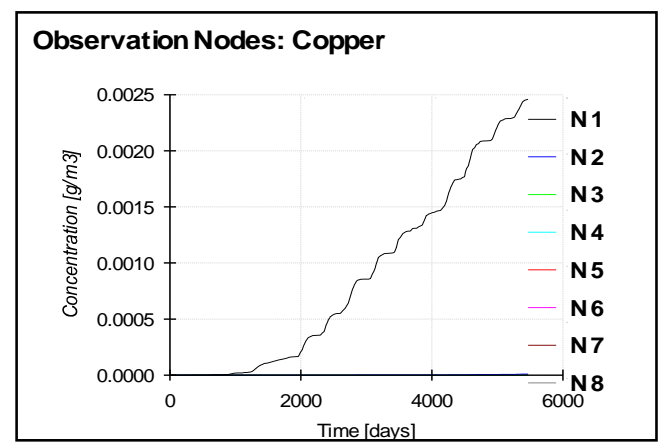

Fig. 2a. Copper concentrations through soil profile with initial concentration of $100 \mathrm{mg} / \mathrm{L}$.

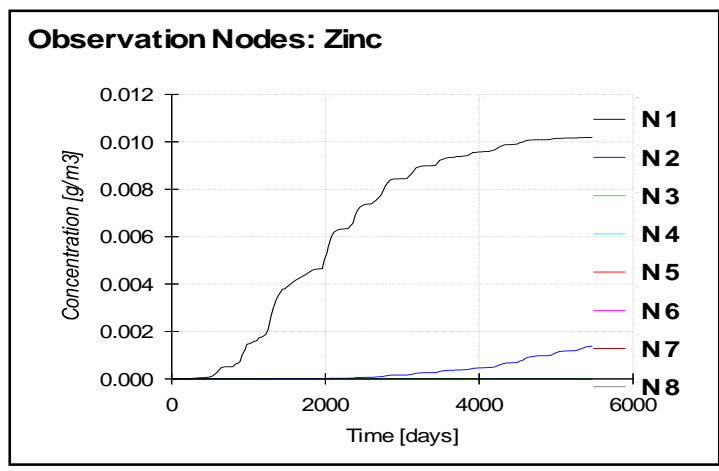

Fig. 2b. Zinc concentrations through soil profile with initial concentration of $100 \mathrm{mg} / \mathrm{L}$.

\section{B. Effects of Adsorption Coefficient, $k_{d}$}

The soil adsorption coefficient $k_{d}$ significantly affects the final concentration of heavy metals in soil. The model was run at default parameters for landfill site but $k_{d}$ values were varied as shown in Table II.

\begin{tabular}{c|c|c|c|c}
\multicolumn{2}{c}{ TABLE II: SUMMARY OF $K_{D}$ VALUE USED AS INPUT IN HYDRUS 1D } \\
\hline \hline $\begin{array}{c}\text { Heavy } \\
\text { Metals }\end{array}$ & \multicolumn{4}{|c}{$k_{d}$ value $\left(\mathrm{m}^{3} / \mathrm{g}\right)$} \\
\hline Copper & $4.0 \times 10^{-5}$ & $4.0 \times 10^{-7}$ & $4.0 \times 10^{-9}$ & 0 \\
Zinc & $1.6 \times 10^{-5}$ & $1.6 \times 10^{-7}$ & $1.6 \times 10^{-9}$ & 0 \\
\hline \hline
\end{tabular}

How leachates are migrated in soil profile for different $k_{d}$ values $\left(k_{d}=4.0 \times 10^{-7}\right.$ and $\left.k_{d}=4.0 \times 10^{-9}\right)$ are shown in Fig. 3 and 4 for Coper and Zinc respectively. This showed that the adsorption coefficient is one of the most important factors influencing the migration of the leachate through the soil profile. Smaller the adsorption coefficient of solutes in soil, the lesser is the solute adsorbed by the soil and hence, the leachate speed increases as the $k_{d}$ value decreases. This showed that under the default $k_{d}$ value in the decimal place of $10^{-5} \mathrm{~m}^{3} / \mathrm{g}$ there are heavy metal leachate being adsorbed into the tamala limestone and therefore, are unable to contaminate the groundwater at the depth of $14 \mathrm{~m}$ profile.

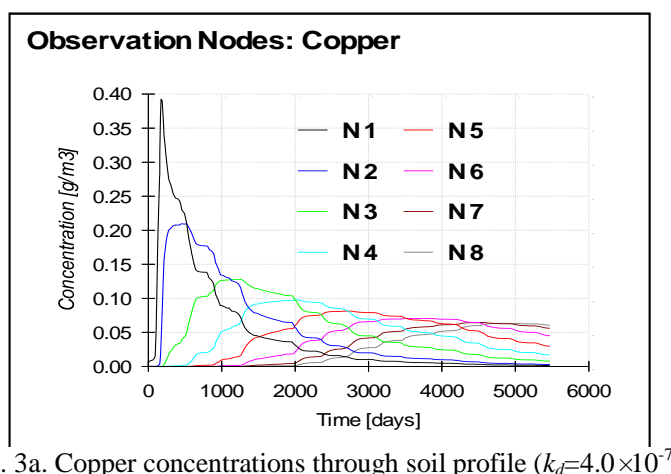

Fig. 3a. Copper concentrations through soil profile $\left(k_{d}=4.0 \times 10^{-7}\right)$.

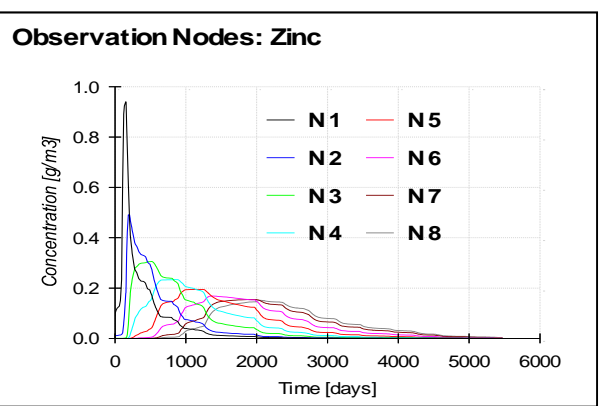

Fig. 3b. Zinc Concentrations through soil profile $\left(k_{d}=4.0 \times 10^{-7}\right)$.

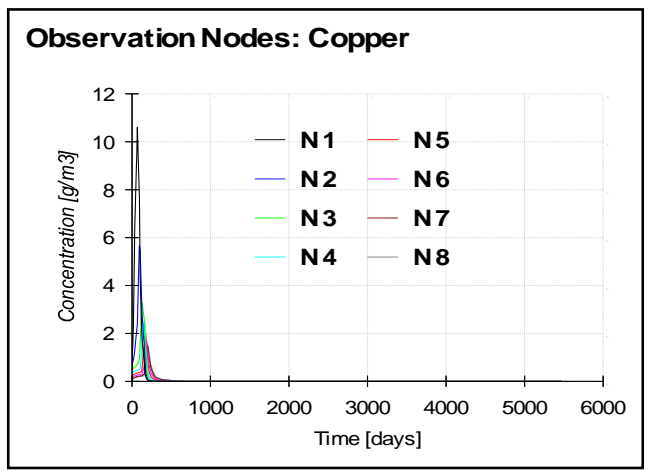

Fig. 4a. Copper concentrations through soil profile $\left(k_{d}=4.0 \times 10^{-9}\right)$.

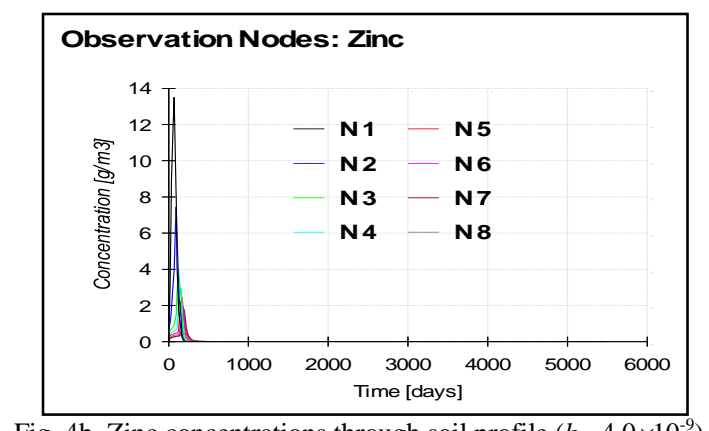

Fig. 4b. Zinc concentrations through soil profile $\left(k_{d}=4.0 \times 10^{-9}\right)$.

The only possibility of reaching the leachate at bottom of the soil profile is if the $k_{d}$ value is 100 times smaller (e.g. $k_{d}=4.0 \times 10^{-9}$ as shown in Fig. $4 \mathrm{a}$ and $4 \mathrm{~b}$ ). The actual $k_{d}$ value of tamala limestone for heavy metals may in fact be much lower than the $k_{d}$ values obtained from average tests on general soil. This may be the reason why few heavy metal concentrations in groundwater were found exceeding the ANZECC guidelines [11]. This revealed that the initial concentration of $100 \mathrm{mg} / \mathrm{L}$ can be dangerous if the absorption coefficient of the particles is very low and allow the particles to leach into the groundwater. The results obtained for the $k_{d}$ values with decimal place of $10^{-9}$ and 0 can said to be almost identical. When $k_{d}=0$, that means heavy metals are not adsorbed by the soil and it may directly leach to groundwater. 
Again, from the nature of the graphs, it is revealed that the leachate migration of two heavy metals studied in this research have similar characteristics.

\section{Effects of Longitudinal Dispersivity, $D_{L}$}

To investigate the effects of longitudinal dispersivity $\left(\mathrm{D}_{L}\right)$, the value of $\mathrm{D}_{L}$ was varied $0.1-1 \mathrm{~m}$. This parameter is considered one of the controlling factors of heavy metals leachate as it provides the mechanical mixing in solute transport. The result revealed that the Copper leachate migration to $1 \mathrm{~m}$ depth decreased from $4^{\text {th }}$ year to $7^{\text {th }}$ year by about $26 \%$ of its default condition. At the end of 15 years, $99.5 \%$ concentration reduction was observed at this depth for Copper. For Zinc leachate to reach at this depth of $1 \mathrm{~m}$, time took about 1.5 years. $27 \%$ of zinc reduction was observed after 5.5 years whereas $76.5 \%$ reduction was observed at the end of 15 years at this depth.

\section{Effect of Initial Water Content, $\theta$}

The initial water contents were varied between $0-0.1$. The result showed that there were only relatively small changes in the concentration of the heavy metals at the $1 \mathrm{~m}$ depth through the soil profile and proved that the effect of initial moisture content has very little impact in this model of heavy metals leachate. The reduction of concentration of heavy metals in soil is not a function of initial water content.

\section{E. Saturated Hydraulic Conductivity, $K_{s}$}

This section of the paper discusses the effects of saturated hydraulic conductivity on landfill leachate transport. The $\mathrm{K}_{s}$ values were taken in the range of $10-1000 \mathrm{~m} /$ day. The results revealed that leachate transport of Copper or Zinc did not have significant effect on the saturated hydraulic conductivity of the soil.

\section{F. Effect of Diffusion Coefficient in Water, $D_{w}$}

The effect of $\mathrm{D}_{w}$ was checked using the Diffusion Coefficient in fresh water and sea water respectively. The diffusion coefficient of heavy metals in sea water was considered because Rottnest Island is a unique site with hypersaline lakes and high saline groundwater. The value of $\mathrm{D}_{w}$ in sea water for Copper and Zinc are taken as $6.33 \times 10^{-5}$ $\mathrm{m}^{2} /$ day and $6.18 \times 10^{-5} \mathrm{~m}^{2} /$ day respectively [15]. The results were found identical to Fig. 1a and $1 \mathrm{~b}$ indicating that there is no effect on diffusion coefficient on leachate transport in soil.

Though the heavy metals concentration of Copper and Zinc in Rottnest groundwater (from boreholes samples near landfill sites during regular monitoring) was found exceeding the ANZECC guidelines [11], the HYDRUS-1D model results did not show significant metal pollution in groundwater from the landfill of Rottnest Island. The highest values of heavy metals were found only at a depth of $1 \mathrm{~m}$ over a period of 15 years, which are $0.00245 \mathrm{mg} / \mathrm{L}$ for Copper and $0.0102 \mathrm{mg} / \mathrm{L}$ for Zinc which are just above the trigger value [11]. However, the ANZECC guidelines given are for freshwater and inshore marine water ecosystem [11], there is no criterion for saline groundwater. Also, the initial concentration of heavy metals deposited on the landfill site is only an estimation taken from the average values of most deposited materials. Therefore, the results presented herein provide an indication how heavy metals leachate are transported in the soil of Rottnest Island.

\section{CONCLUSIONS}

The HYDRUS-1D model was used to investigate the heavy metal migration at a landfill site of Rottnest Island, Western Australia. Two heavy metals Zinc and Copper were selected for this study as these two were found in higher concentration in Rottnest groundwater. The contaminant migration of these two heavy metals were modelled for different solute transport parameters including initial concentration, soil adsorption coefficient, longitudinal dispersion, saturated hydraulic conductivity, initial soil water content and water diffusion coefficient. The results revealed that soil adsorption parameter is the most dominating factors for leachate transport in landfill site. The initial concentration also shows significant effect on mass transport in soil. The longitudinal dispersion was found affecting moderately on leachate migration but water diffusion coefficient has no effect. The initial soil moisture and saturated hydraulic conductivity shows minimum effect on leachate transport in soil. However, the values for different parameters used in this research were taken from different literatures. The actual values may be obtained from experiments using Rottnest soil and can be used in models to get more realistic results.

\section{ACKNOWLEDGMENT}

Authors gratefully acknowledge the in-kind support provided by the Rottnest Island Authority for visiting the island and collecting data.

\section{REFERENCES}

[1] M. Aucott, “"The fate of heavy metals in landfills: A Review, Prepared for the 'Industrial Ecology, Pollution Prevention and the NY-NJ Harbor'," Project of the NY Academy Sciences, Feb. 2006.

[2] D. L. Jensen and T. H. Christensen, "Colloidal and dissolved metals in leachate from four Danish landfills," Water Research, vol. 33, no. 9 , pp. 2139-2147, 1999.

[3] H. D. Robinson and J. L. Lucas, "Leachate attenuation in the unsaturated zone beneath landfills: instrumentation and monitoring of a site in southern England," Water Science \& Technology, vol. 17, pp. 477-492, 1985.

[4] J. K. Oygard, A. Mage, and E. Gjengedal, "Estimation of the mass balance of selected metals in four sanitary landfills in Western Norway, with emphasis on the heavy metals content of the deposited waste and the leachate," Water Research, vol. 38, no. 12, pp. 2851-2858, 2004.

[5] D. Rapti-Caputo and C. Vaccaro, "Geochemical evidences of landfill leachate in groundwater," Engineering Geology, vol. 85, pp. 111-121, 2006.

[6] T. M. Addiscott and R. J. Wagenet, "Concepts of solute leaching in soils: a review of modelling approaches," J. of Soil Science, vol. 36, pp. 411-424, 1985.

[7] M. A. Martin, "Mathematical modelling of leaching by irregular wetting fronts in chemically heterogeneous porous media," Geoderma, vol. 134, pp. 267-273, 2006.

[8] J. D. Vilomet, A. Veron, I. J. P. Ambrosi, S. Moustier, J. Y. Bottero, and L. Chatelet-Snidaro, "Isotopic tracing of landfill leachate and pollutant lead mobility in soil and groundwater," Environmental Science and Technology, vol. 37, pp. 4586-4591, 2003.

[9] A. L. Walter, E. O. Frind, D. W. Blowers, C. J. Ptacek, and J. W. Molson, "Modeling of multicomponent reactive transport in groundwater: 1. Model development and evaluation," Water Resources Research, vol. 30, no. 11, pp. 3137-3148, 1994.

[10] A. H. M. F. Anwar and P. Wawn, "Freshwater discharge to salt lake and its implications for freshwater management at Rottnest Island, Western Australia," in Proc. 35th IAHR World Congress, Chengdu, China, 8-13 September, 2013.

[11] ANZECC, Australian and New Zealand Guidelines for Fresh and Marine Water Quality, Australian and New Zealand Environment and Conservation Council, 2000.

[12] Rottnest Island Authority (RIA), Annual Environmental Report, p. 22, Sep. 2005-Jun. 2006 
[13] J. Simunek, M. T. van Genuchten, and M. Sejna, "The HYDRUS-1D software package for simulating the one-dimensional movement of water, heat and multiple solutes in variably-saturated media," User's Manual Version 3.0, University of California, Riverside, USA, 2005.

[14] S. Roulier, N. Baran, C. Mouvet, F. Stenemo, X. Morvan, H. J. Albrechtsen, L. Clausen, and N. Jarvis, "Controls on atrazine leaching through a soil-unsaturated fractured limestone sequence at Brevilles, France," J. Contaminant Hydrology, vol. 84, pp. 81-105, 2006.

[15] Y. H. Li and S. Gregory, "Diffusion of ions in seawater and deep-sea sediments," Geochimica et Cosmochimica Acta, vol. 38, pp. 703-714, 1974.

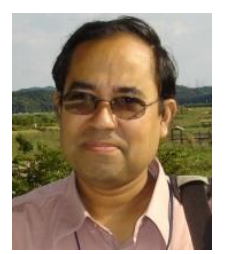

A. H. M. Faisal Anwar received his $\mathrm{PhD}$ degree in civil engineering (environmental) from Nagoya University, Japan in 2000. Currently he is working as an associate professor in the Department of Civil Engineering at Curtin University in Western Australia. Prior to joining Curtin, he served as a lecturer, assistant professor and associate professor in the Department of Water Resources Engineering at Bangladesh University of Engineering and Technology. He also worked as a postdoctoral research fellow in the Graduate School of Environmental Sciences at Nagoya University, Japan. He is the recipient of Pro-Vice Chancellor's Teaching Excellence Award 2011, Vice-Chancellor's Teaching Excellence Award 2012 of Curtin University and a National Citation Award 2013 for outstanding contribution to student learning from the Office for Learning and Teaching, Australian Government. His research interests include groundwater and aquifer dynamics, stormwater/greywater management and climate change effect on water resources. 